\title{
The role of anion in the impact of tetraethylammonium salts on soil phosphatase activities
}

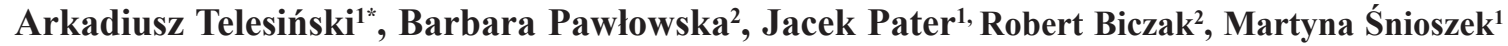 \\ ${ }^{1}$ Department of Plant Physiology and Biochemistry, West Pomeranian University of Technology in Szczecin, \\ Słowackiego 17 St, 71-434 Szczecin, \\ *e-mail: arkadiusz.telesinski@zut.edu.pl \\ ${ }^{2}$ Department of Biochemistry and Ecotoxicology, Jan Długosz University in Częstochowa, Armii Krajowej 13/15 St, \\ 42-200 Częstochowa
}

Received: 30 August 2017 /Accepted: 12 November 2017

\begin{abstract}
Quaternary ammonium salts (QAS) are increasingly commonly used in the chemical industry. The diverse usage of these compounds results in high possibility of their penetration to the environment. The aim of this study was to compare the effect of three salts with tetraethylammonium cation with different anions such as chloride [TEA][Cl], bromide [TEA][Br], and iodine [TEA][I] on the activity of phosphatases in loamy sand. Organic carbon and total nitrogen content in the soil were 8.71 and $0.97 \mathrm{~g} \cdot \mathrm{kg}^{-1}$, respectively. The salts were applied to soil at doses of $0,0.05,0.50$, and $5.00 \mathrm{mmol} \cdot \mathrm{kg}^{-1}$. The samples were adjusted to $60 \%$ maximum water holding capacity, and they were incubated at a temperature of $20^{\circ} \mathrm{C}$. Activities of acid phosphomonoesterase, alkaline phopshomonoesterase, phosphotriesterase, and inorganic pyrophosphatase were assayed on day $1,7,14,28,56$, and 112 . The obtained results demonstrated that the presence of [TEA] in the soil at the low dose $\left(0.05 \mathrm{mmol} \cdot \mathrm{kg}^{-1}\right)$ may stimulate the activity of soil phosphatases. Higher doses of the soil had mostly inhibitory effect on phosphatases activity. Among the determined enzymes, phosphomonoesterases were the most sensitive to salts containing [TEA] cation. A considerable contribution of the anion type on the formation of activity of the determined enzymes of phosphorus compound changes. The strongest effect characterized tetraethylammonium bromide [TEA][Br].
\end{abstract}

Key words: quaternary ammonium salts, loamy sand, acid phosphomonoesterase, alkaline phosphomonoesterase, phosphotriesterase, inorganic pyrophosphatase.

\section{Introduction}

Due to their numerous useful properties, quaternary ammonium salts (QAS), including ionic liquids, are increasingly commonly used in the chemical industry (Park \& Kim, 2017). Considering the chemical structure, these substances are included in the ionic compounds containing four organic groups per molecule, bound with nitrogen atoms (three covalent and one dipolar bond) (Pernak, 2013).

According to the literature data, the annual QAS production exceeds the amount of 1 million tons, and the demand continues to increase (Telesiński et al., 2016a). These substances are typically used at low concentrations; thus, the production level proves their immense economic importance (Grabińska-Sota, 2004). The diverse usage of quaternary ammonium salts results in high possibility of their penetration to the environment, directly or indirectly with domestic and industrial sewage or rain water (Biczak et al., 2016).

Soil is a living, dynamic ecosystem, and the fate of chemical substances including newly synthesized quaternary ammonium salts must be constantly monitored. 
The literature concerned with the comprehensive assessment of ecotoxicity of ionic liquids on soil is scarce; therefore, the near future study on relationship between toxicity of ILs and soil parameters such as acidity, moisture, colloids amount, granulometric composition, or soil sorption capacity is required (Biczak et al., 2014).

Based on the enzymatic activity, the effect of contaminants on the eco-chemical state of soil can be properly evaluated (Wang et al., 2015; Futa et al., 2016). Soil enzymes are often referred to as biochemical and microbial soil activity indexes (Burns et al., 2013). Phosphatases are included in a large group of enzymes, catalyzing the hydrolysis of organic phosphorus bonds, and are used for the evaluation of the potential rate of mineralization of these substances in soil (Płatkowski \& Telesiński, 2016). As provided by Olander and Vitousek (2000), the activity of phosphatases in soil environment reflects the activity of enzymes linked to soil colloids and humus substances. Phosphatases are also considered to be good indexes of organic phosphorus mineralization potential and soil biological activity (Banerjee et al., 2012).

The majority of research concerning ecotoxic influence of ionic liquids focuses on the comparison of the effect of cation and the length of alkyl substituents on the selected biochemical, microbial, or physiological parameters. However, information on the influence of anion is limited. Matzke et al. (2007) have assessed the acute toxicity of 1-alkyl-3-methylimidazolium bonded with six organic and inorganic anions against marine and land organisms living on various levels of food chain including marine bacteria, algae, duckweed, wheat, and cress. Biczak et al. (2014) reported that for the common radish, the anion type was crucial the occurred toxicity of the compound to this plant, though no regularity of that effect could be observed. Telesiński et al. (2016b) who studied two 1-butyl-2,3-dimethylimidiazolium ionic liq- uids with anions, such as tetrafluoroborate and hexafluorophosphate, observed inhibition of the activity of soil enzymes, increasing with the increased dose of the analyzed substances. However, it was difficult to indicate which of the analyzed salts had stronger effect on the determined biochemical parameters of soil.

Thus, the conducted study aimed at comparing the effect of three tetraethylammonium salts with anions: chloride $[\mathrm{TEA}][\mathrm{Cl}]$, bromide $[\mathrm{TEA}][\mathrm{Br}]$, and iodine [TEA] [I] on alkaline phosphomonoesterase [EC 3.1.3.1], acid phosphomonoesterase [EC 3.1.3.2], phosphotriesterase [EC 3.1.8.1], and inorganic pyrophosphatase [EC 3.6.1.1] in sandy soil.

\section{Material and methods}

The testing was performed on a soil material collected from the topsoil of Brunic Arenosol in Agricultural Experimental Station in Lipnik $\left(53^{\circ} 34^{\prime} \mathrm{N}, 14^{\circ} 97^{\prime} \mathrm{E}\right)$, located in the West Pomeranian District, Poland. According to the classification of the United States Department of Agriculture, it was soil with a granulometric composition of loamy sand. The content of particular fractions, expressed in $\mathrm{g} \cdot \mathrm{kg}^{-1}$, was as follows: sand $(0.05-2 \mathrm{~mm})-$ 748.6; silt $(0.002-0.05 \mathrm{~mm})-231.3$; and clay $(<0.002$ $\mathrm{mm})-20.1$. The soil contained, expressed in $\mathrm{g} \cdot \mathrm{kg}^{-1}$ : $\mathrm{C}_{\text {org }}-8.71 ; \mathrm{N}_{\text {tot }}-0.97$. Its hydrolytic acidity was 9.9 $\mathrm{mmol}(+) \cdot \mathrm{kg}^{-1}$ and the $\mathrm{pH}$ value in $1 \mathrm{M} \mathrm{KCl}$ was 6.4 . The soil was air-dried soil and sieved with a mesh size of $2 \mathrm{~mm}$.

Three tetraethylammonium salts with different anions such as chloride [TEA][Cl], bromide [TEA][Br], and iodine [TEA] [I] at the doses of $0,0.05,0.50$, and $5.00 \mathrm{mmol} \cdot \mathrm{kg}^{-1}$, were added to soil (Table 1 ). The samples were adjusted to $60 \%$ maximum water holding ca-

Table 1. Doses of [TEA] salts added to soil

\begin{tabular}{|c|c|c|c|c|}
\hline $\begin{array}{l}\text { Dosage of salts } \\
\left(\mathbf{m m o l} \cdot \mathrm{kg}^{-1}\right)\end{array}$ & Salt & $\begin{array}{l}\text { Dosage of salts } \\
\quad\left(\mathrm{mg} \cdot \mathrm{kg}^{-1}\right)\end{array}$ & $\begin{array}{c}\text { Dosage of anion } \\
\left(\mathrm{mg} \cdot \mathrm{kg}^{-1}\right)\end{array}$ & $\begin{array}{c}\text { Dosage of [TEA] } \\
\text { cation } \\
\left(\mathrm{mg} \cdot \mathrm{kg}^{-1}\right)\end{array}$ \\
\hline \multirow{3}{*}{0.05} & {$[\mathrm{TEA}][\mathrm{Cl}]$} & 8.29 & 1.77 & \multirow{3}{*}{6.51} \\
\hline & {$[\mathrm{TEA}][\mathrm{Br}]$} & 10.51 & 4.00 & \\
\hline & [TEA][I] & 12.86 & 6.35 & \\
\hline \multirow{3}{*}{0.50} & {$[\mathrm{TEA}][\mathrm{Cl}]$} & 82.90 & 17.70 & \multirow{3}{*}{65.10} \\
\hline & {$[\mathrm{TEA}][\mathrm{Br}]$} & 105.10 & 40.00 & \\
\hline & {$[\mathrm{TEA}][\mathrm{I}]$} & 128.60 & 63.50 & \\
\hline \multirow{3}{*}{5.00} & {$[\mathrm{TEA}][\mathrm{Cl}]$} & 829.00 & 177.00 & \multirow{3}{*}{651.00} \\
\hline & {$[\mathrm{TEA}][\mathrm{Br}]$} & 1051.00 & 400.00 & \\
\hline & [TEA][I] & 1286.00 & 635.00 & \\
\hline
\end{tabular}


pacity, and they were incubated in tightly closed glass containers at a temperature of $20^{\circ} \mathrm{C}$.

Activities of alkaline phosphomonoesterase, acid phosphomonoesterase, phosphotriesterase, and inorganic pyrophosphatase were assayed on days 1, 7, 14, 28, 56, and 112. The acid phosphomonoesterase (Pac) and alkaline phosphomonoesterase (Pal) activities were determined as described by Tabatabai and Bremner (1969). The phosphotriesterase (PT) activity was determined according to Eivazi and Tabatabai (1977). Due to pnitrophenol, the yellow-band absorbance of the filtrate was measured at $400 \mathrm{~nm}$. Based on Dick and Tabatabai (1978) method, the inorganic pyrophosphatase (IPP) activity was measured. Released orthophosphate was extracted with sulfuric acid and determined photometrically at $700 \mathrm{~nm}$ after colorization with ammonium molybdate. Enzyme activities were calculated using a calibration curve. Shimadzu UV-VIS 1800 equipment was used in all measurements.

Phosphatase activity determinations were performed on three replicates for each treatment, and the significance of the observed differences was verified using a one-way analysis of variance followed by the post-hoc Tukey's HSD test. Differences with a $p$ value of $<0.05$ were considered as significant.

In addition, the mean activity of phosphatases of samples treated with all doses of [TEA] salts was used to calculate the index of enzymatic resistance (RS) according to the formula developed by Orwin and Wardle (2004):

$$
R S=1-\frac{2|D|}{C+|D|}
$$

where $\mathrm{C}$ is the soil resistance under natural conditions (not exposed to [TEA] salts) and $\mathrm{P}$ the resistance of soil exposed to [TEA] salts

$$
D=C-P
$$

\section{Results and discussion}

The Pac activity in soil with addition of [TEA][Br] at the dose of $0.05 \mathrm{mmol} \cdot \mathrm{kg}^{-1}$ during the entire experiment was significantly higher than in the control soil and the observed stimulation remained at the level between $15.65 \%$ and $32.35 \%$. Application of the remaining salts resulted in increased Pac activity only in the period between day 14 and 56, which was at its maximum for [TEA] [Cl] 28.32\% (day 56) and for [TEA][I] 25.23\% (day 14). On the contrary, application of the dose of $0.50 \mathrm{mmol} \cdot \mathrm{kg}^{-1}$ resulted in a statistically significant decrease of Pac activity for [TEA] $[\mathrm{Cl}]$ on day 56 and 112 (14.46\% and $10.10 \%$, respectively) and for [TEA][Br] from day 14 till the end of the experiment (17.88-25.17\%). In soil with addition of each of the [TEA] salts at the dose of $5.00 \mathrm{mmol} \cdot \mathrm{kg}^{-1}, \mathrm{Pac}$ activity during the entire experiment was lower than in the control soil and the observed inhibition for [TEA][Cl], [TEA] $[\mathrm{Br}]$, and [TEA][I] was $13.33-48.56 \%, 35.47-65.55 \%$, and $15.35-46.66 \%$, respectively (Table 2 ).

\begin{tabular}{|c|c|c|c|c|c|c|c|}
\hline \multirow{2}{*}{$\begin{array}{l}\text { Dose of [TEA] salt } \\
\left(\mathrm{mmol} \cdot \mathrm{kg}^{-1}\right)\end{array}$} & \multirow{2}{*}{ Anion } & \multicolumn{6}{|c|}{ Day of experiment } \\
\hline & & 1 & 7 & 14 & 28 & 56 & 112 \\
\hline \multicolumn{2}{|c|}{ Control } & $120.43^{\mathrm{bc}}$ & $122.74^{\mathrm{bc}}$ & $119.32^{\mathrm{b}}$ & $121.93^{b}$ & $118.39^{b}$ & $116.02^{\mathrm{bc}}$ \\
\hline \multirow{3}{*}{0.05} & {$[\mathrm{Cl}]$} & $136.63^{b}$ & $134.47^{b}$ & $145.36^{\mathrm{a}}$ & $139.39^{\mathrm{a}}$ & $151.92^{\mathrm{a}}$ & $126.15^{\mathrm{b}}$ \\
\hline & {$[\mathrm{Br}]$} & $152.38^{\mathrm{a}}$ & $162.32^{\mathrm{a}}$ & $146.04^{\mathrm{a}}$ & $141.01^{\mathrm{a}}$ & $153.26^{\mathrm{a}}$ & $139.15^{\mathrm{a}}$ \\
\hline & {$[\mathrm{I}]$} & $131.81^{\mathrm{b}}$ & $137.90^{\mathrm{b}}$ & $149.42^{\mathrm{a}}$ & $135.89^{\mathrm{a}}$ & $147.77^{a}$ & $126.04^{\mathrm{b}}$ \\
\hline \multirow{3}{*}{0.50} & {$[\mathrm{Cl}]$} & $110.84^{\mathrm{c}}$ & $109.66^{\mathrm{c}}$ & $119.83^{b}$ & $111.24^{\mathrm{bc}}$ & $101.27^{\mathrm{cd}}$ & $104.30^{\text {de }}$ \\
\hline & {$[\mathrm{Br}]$} & $101.81^{\mathrm{c}}$ & $108.27^{\mathrm{c}}$ & $89.31^{\mathrm{c}}$ & $100.13^{c}$ & $90.75^{\mathrm{d}}$ & $87.12^{\mathrm{f}}$ \\
\hline & {$[\mathrm{I}]$} & $108.65^{c}$ & $109.15^{\mathrm{c}}$ & $111.39^{\mathrm{b}}$ & $121.13^{b}$ & $112.51^{\mathrm{b}}$ & $108.29^{\mathrm{cd}}$ \\
\hline \multirow{3}{*}{5.00} & {$[\mathrm{Cl}]$} & $78.26^{\mathrm{d}}$ & $77.76^{\mathrm{d}}$ & $64.36^{\mathrm{d}}$ & $62.72^{\mathrm{e}}$ & $66.69^{\mathrm{e}}$ & $100.55^{\mathrm{de}}$ \\
\hline & {$[\mathrm{Br}]$} & $77.71^{\mathrm{d}}$ & $42.28^{\mathrm{e}}$ & $50.46^{\mathrm{e}}$ & $59.44^{\mathrm{e}}$ & $73.65^{\mathrm{e}}$ & $64.91^{\mathrm{g}}$ \\
\hline & {$[\mathrm{I}]$} & $84.11^{\mathrm{d}}$ & $72.23^{\mathrm{d}}$ & $63.65^{\mathrm{d}}$ & $75.88^{\mathrm{d}}$ & $92.85^{\mathrm{d}}$ & $98.21^{\mathrm{ef}}$ \\
\hline
\end{tabular}

Table 2. Activity of acid phosphomonoesterase in soil untreated and treated with [TEA] salts $\left[\mathrm{mg} \mathrm{p}-\mathrm{NP} \cdot \mathrm{kg}^{-1} \mathrm{dm} \cdot \mathrm{h}^{-1}\right]$

Values denoted with the same letter for each day do not differ statistically at $p<0.05$ 
After the application of [TEA][Cl] and $[\mathrm{TEA}[\mathrm{I}]$ at the dose of $0.05 \mathrm{mmol} \cdot \mathrm{kg}^{-1}$, the Pal activity during the entire experiment was statistically significantly higher in comparison to the control. The observed stimulation of activity was at the level from $8.93 \%$ to $26.65 \%$ and $8.82 \%$ to $17.93 \%$, respectively. On the contrary, the application of [TEA][Br] at the above dose resulted in a statistically significant inhibition of Pal activity only on day 28 and 56 (in relation to control $12.26 \%$ and $9.97 \%$, respectively). Addition of higher doses of [TEA] salts mostly resulted in a decrease of Pal activity. For the dose of $0.50 \mathrm{mmol} \cdot \mathrm{kg}^{-1}$, in the case of [TEA][Cl] and [TEA][Br], the effect was observed during the entire experiment and the inhibition remained at the level of $6.97-20.07 \%$ and $11.79-25.15 \%$, respectively, in reference to the control. In the case of [TEA][I], statistically significant decrease of Pal activity occurred from day 7 to day $56(14.45-18.89 \%)$. But, application of all [TEA] salts at the dose of $5.00 \mathrm{mmol} \cdot \mathrm{kg}^{-1}$ resulted in Pal activity inhibition during the entire experiment, which for [TEA][Cl], [TEA][Br], and [TEA][I] was 30.57-46.67\%, $51.47-70.06 \%$ and $34.45-48.88 \%$ respectively (Table 3 ).

The activity of PT in soil containing [TEA][Cl] at the dose of $0.05 \mathrm{mmol} \cdot \mathrm{kg}^{-1}$ during the experiment was $8.93-20.21 \%$ statistically higher than the control. A stimulation of PT activity was also observed from day 7 till the end of the experiment after application of [TEA][I] $(9.93-16.66 \%)$ and on day 56 after addition of [TEA][Br] (9.35\%). Furthermore, inhibition of PT activity occurred on day 7 in soil with addition of [TEA][Br] $(7.79 \%)$. An application of higher doses of [TEA][Br] resulted in a decrease of activity of PT in comparison to control during the entire experimental period, which was 0.50 and 5.00 $\mathrm{mmol} \cdot \mathrm{kg}^{-1}$, respectively, $9.98-17.06 \%$ and $14.48-31.07 \%$ (Table 4). Addition of [TEA][Cl] and [TEA][I] only at the dose of $5.00 \mathrm{mmol} \cdot \mathrm{kg}^{-1}$ resulted in the inhibition of PT activity during the entire experimental period (at the level of $14.44-27.77 \%$ and $11.68-18.96 \%$, respectively). On the contrary, in the soil containing the dose of $0.50 \mathrm{mmol} \cdot \mathrm{kg}^{-1}$ of these salts, the activity of PT was statistically significantly lower than in the control on day 1, 7, and 112 in the case of [TEA][Cl] $(7.77 \%, 9.97 \%$ and $7.68 \%$, respectively) and on day 28 and 112 [TEA][I] (correspondingly $14.02 \%$ and $8.88 \%$ ).

The IPP activity was characterized by the lowest changes under the influence of [TEA] salts. Statistically significant stimulation of IPP activity was observed solely for the soil containing [TEA][Cl] at the dose of $0.05 \mathrm{mmol} \cdot \mathrm{kg}^{-1}$ from day 7 till the end of the experiment $(9.43-21.93 \%$ in relation to the control) and in the soil with the addition of [TEA][I] at the same dose on day 56 (16.66\% compared to the control). Statistically significant reduction of IPP activity was demonstrated after the application of [TEA] [Br] at the dose of $0.50 \mathrm{mmol} \cdot \mathrm{kg}^{-1}$ on day $1,7,56(8.88 \%$, $14.46 \%$ and $11.68 \%$, respectively) and at the dose of 5.00 $\mathrm{mmol} \cdot \mathrm{kg}^{-1}$ during the entire experimental period (11.46$19.35 \%$ ), while in the case of [TEA][Cl] and [TEA][I], the statistically significant inhibition of IPP activity was only found for the dose of $5.00 \mathrm{mmol} \cdot \mathrm{kg}^{-1}$ on days $1,7,56$, and 112 (Table 5).

The obtained results demonstrated that the presence of [TEA] in soil at the low dose $\left(0.05 \mathrm{mmol} \cdot \mathrm{kg}^{-1}\right) \mathrm{might}$ stimulate the activity of soil phosphatases. However, the occurrence of higher salt concentrations mostly resulted in the reduction of activity of these enzymes. Changes in

Table 3. Activity of alkaline phosphomonoesterase in soil untreated and treated with [TEA] salts [mg p-NP· $\left.\mathrm{kg}^{-1} \mathrm{dm} \cdot \mathrm{h}^{-1}\right]$

\begin{tabular}{|c|c|c|c|c|c|c|c|}
\hline \multirow{2}{*}{$\begin{array}{l}\text { Dose of [TEA] salt } \\
\quad\left(\mathrm{mmol} \cdot \mathrm{kg}^{-1}\right)\end{array}$} & \multirow{2}{*}{ Anion } & \multicolumn{6}{|c|}{ Day of experiment } \\
\hline & & 1 & 7 & 14 & 28 & 56 & 112 \\
\hline \multicolumn{2}{|c|}{ Control } & $333.08^{c}$ & $329.73^{c}$ & $338.92^{\mathrm{c}}$ & $331.29^{\mathrm{c}}$ & $320.03^{b}$ & $325.55^{\mathrm{c}}$ \\
\hline \multirow{3}{*}{0.05} & {$[\mathrm{Cl}]$} & $412.42^{\mathrm{a}}$ & $359.17^{b}$ & $429.24^{\mathrm{a}}$ & $407.19^{\mathrm{a}}$ & $369.73^{\mathrm{a}}$ & $390.43^{\mathrm{a}}$ \\
\hline & {$[\mathrm{Br}]$} & $340.67^{\mathrm{cd}}$ & $328.05^{c}$ & $312.52^{\mathrm{cd}}$ & $290.67^{d}$ & $288.12^{c}$ & $322.59^{\mathrm{cd}}$ \\
\hline & {$[\mathrm{I}]$} & $377.45^{\mathrm{b}}$ & $388.85^{\mathrm{a}}$ & $388.00^{\mathrm{b}}$ & $360.51^{\mathrm{b}}$ & $359.36^{\mathrm{a}}$ & $354.62^{b}$ \\
\hline \multirow{3}{*}{0.50} & {$[\mathrm{Cl}]$} & $309.86^{\text {de }}$ & $291.22^{\mathrm{d}}$ & $281.34^{\mathrm{d}}$ & $264.80^{\mathrm{e}}$ & $273.75^{c}$ & $292.73^{\mathrm{d}}$ \\
\hline & {$[\mathrm{Br}]$} & $281.59^{\mathrm{e}}$ & $290.85^{d}$ & $253.68^{\mathrm{ef}}$ & $272.06^{\mathrm{e}}$ & $245.30^{\mathrm{d}}$ & $244.46^{\mathrm{e}}$ \\
\hline & {$[\mathrm{I}]$} & $318.19^{\text {cd }}$ & $282.08^{\mathrm{d}}$ & $279.07^{\mathrm{de}}$ & $268.71^{\mathrm{e}}$ & $273.72^{c}$ & $303.48^{\text {cd }}$ \\
\hline \multirow{3}{*}{5.00} & {$[\mathrm{Cl}]$} & $195.35^{\mathrm{f}}$ & $175.85^{\mathrm{e}}$ & $235.31^{\mathrm{f}}$ & $207.19^{\mathrm{f}}$ & $214.16^{\mathrm{e}}$ & $193.12^{\mathrm{f}}$ \\
\hline & {$[\mathrm{Br}]$} & $161.64^{\mathrm{g}}$ & $135.58^{\mathrm{f}}$ & $129.87^{\mathrm{h}}$ & $99.19^{\mathrm{g}}$ & $106.73^{\mathrm{f}}$ & $137.41^{\mathrm{g}}$ \\
\hline & {$[\mathrm{I}]$} & $177.66^{\mathrm{fg}}$ & $168.56^{\mathrm{e}}$ & $186.71^{\mathrm{g}}$ & $200.86^{\mathrm{f}}$ & $209.78^{\mathrm{e}}$ & $195.43^{\mathrm{f}}$ \\
\hline
\end{tabular}

Values denoted with the same letter for each day do not differ statistically at $p<0.05$ 
Table 4. Activity of phosphotriesterase in soil untreated and treated with [TEA] salts $\left[\mathrm{mg} \mathrm{p}-\mathrm{NP} \cdot \mathrm{kg}^{-1} \mathrm{dm} \cdot \mathrm{h}^{-1}\right]$

\begin{tabular}{|c|c|c|c|c|c|c|c|}
\hline \multirow{2}{*}{$\begin{array}{l}\text { Dose of [TEA] salt } \\
\quad\left(\mathrm{mmol} \cdot \mathrm{kg}^{-1}\right)\end{array}$} & \multirow{2}{*}{ Anion } & \multicolumn{6}{|c|}{ Day of experiment } \\
\hline & & 1 & 7 & 14 & 28 & 56 & 112 \\
\hline \multicolumn{2}{|c|}{ Control } & $14.84^{\mathrm{bc}}$ & $15.32^{\mathrm{b}}$ & $14.21^{\mathrm{bc}}$ & $15.03^{\mathrm{bc}}$ & $14.44^{c}$ & $14.39^{\mathrm{b}}$ \\
\hline \multirow{3}{*}{0.05} & {$[\mathrm{Cl}]$} & $16.67^{\mathrm{a}}$ & $16.69^{\mathrm{a}}$ & $15.91^{\mathrm{a}}$ & $17.36^{\mathrm{a}}$ & $17.36^{\mathrm{a}}$ & $16.04^{\mathrm{a}}$ \\
\hline & {$[\mathrm{Br}]$} & $14.02^{\mathrm{cd}}$ & $14.13^{\mathrm{cd}}$ & $14.26^{\mathrm{b}}$ & $15.69^{\mathrm{b}}$ & $15.79^{b}$ & $14.17^{\mathrm{b}}$ \\
\hline & {$[\mathrm{I}]$} & $15.83^{\mathrm{ab}}$ & $17.19^{\mathrm{a}}$ & $15.62^{\mathrm{a}}$ & $17.04^{\mathrm{a}}$ & $16.85^{\mathrm{ab}}$ & $15.82^{\mathrm{a}}$ \\
\hline \multirow{3}{*}{0.50} & {$[\mathrm{Cl}]$} & $13.69^{\text {def }}$ & $13.79^{\text {cde }}$ & $14.13^{\mathrm{bc}}$ & $14.36^{\mathrm{c}}$ & $13.48^{\mathrm{cd}}$ & $13.28^{\mathrm{c}}$ \\
\hline & {$[\mathrm{Br}]$} & $13.12^{\mathrm{defg}}$ & $13.10^{\mathrm{efg}}$ & $12.11^{\mathrm{e}}$ & $12.47^{\mathrm{fgh}}$ & $12.75^{\mathrm{de}}$ & $12.95^{\text {cde }}$ \\
\hline & {$[\mathrm{I}]$} & $14.18^{\mathrm{cd}}$ & $14.64^{\mathrm{bc}}$ & $13.29^{\mathrm{bcd}}$ & $12.92^{\text {defgh }}$ & $13.48^{\mathrm{cd}}$ & $13.11^{\mathrm{cd}}$ \\
\hline \multirow{3}{*}{5.00} & {$[\mathrm{Cl}]$} & $11.94^{\mathrm{h}}$ & $12.23^{\mathrm{fg}}$ & $10.26^{\mathrm{g}}$ & $12.01^{\mathrm{h}}$ & $11.74^{\mathrm{f}}$ & $12.31^{\mathrm{def}}$ \\
\hline & {$[\mathrm{Br}]$} & $10.23^{i}$ & $11.43^{\mathrm{g}}$ & $11.07^{\mathrm{fg}}$ & $12.85^{\text {efgh }}$ & $10.10^{\mathrm{g}}$ & $11.13^{\mathrm{g}}$ \\
\hline & {$[\mathrm{I}]$} & $12.53^{\mathrm{gh}}$ & $13.53^{\text {def }}$ & $11.80^{\mathrm{ef}}$ & $12.18^{\mathrm{gh}}$ & $12.35^{\mathrm{ef}}$ & $12.63^{\text {cdef }}$ \\
\hline
\end{tabular}

Values denoted with the same letter for each day do not differ statistically at $p<0.05$

Table 5. Activity of inorganic pyrophosphatase in soil untreated and treated with [TEA] salts $\left[\mathrm{mg}\right.$ P-PO $\left.{ }_{4}^{3-\cdot} \cdot \mathrm{kg}^{-1} \mathrm{dm} \cdot \mathrm{h}^{-1}\right]$

\begin{tabular}{|c|c|c|c|c|c|c|c|}
\hline \multirow{2}{*}{$\begin{array}{l}\text { Dose of [TEA] salt } \\
\left(\mathrm{mmol} \cdot \mathrm{kg}^{-1}\right)\end{array}$} & \multirow{2}{*}{ Anion } & \multicolumn{6}{|c|}{ Day of experiment } \\
\hline & & 1 & 7 & 14 & 28 & 56 & 112 \\
\hline \multicolumn{2}{|c|}{ Control } & $172,94^{\mathrm{abc}}$ & $183,23^{\mathrm{bc}}$ & $193,32^{\mathrm{bc}}$ & $188,43^{\text {bc }}$ & $191,32^{b}$ & $199,32^{\mathrm{bc}}$ \\
\hline \multirow{3}{*}{0.05} & {$[\mathrm{Cl}]$} & $184,41^{\mathrm{ab}}$ & $205,60^{\mathrm{a}}$ & $211,55^{\mathrm{a}}$ & $229,75^{\mathrm{a}}$ & $219,67^{a}$ & $227,86^{\mathrm{a}}$ \\
\hline & {$[\mathrm{Br}]$} & $161,42^{\text {cdef }}$ & $187,32^{\mathrm{b}}$ & $194,58^{\mathrm{bc}}$ & $173,90^{\mathrm{cd}}$ & $184,93^{\mathrm{bc}}$ & $208,13^{\mathrm{bc}}$ \\
\hline & [I] & $184,44^{\mathrm{a}}$ & $187,32^{\mathrm{b}}$ & $201,86^{\mathrm{ab}}$ & $203,01^{\mathrm{b}}$ & $223,19^{\mathrm{a}}$ & $219,17^{\mathrm{ab}}$ \\
\hline \multirow{3}{*}{0.50} & {$[\mathrm{Cl}]$} & $170,92^{\mathrm{cd}}$ & $177,08^{\mathrm{cd}}$ & $184,74^{\mathrm{cd}}$ & $175,88^{\mathrm{c}}$ & $184,89^{\mathrm{bc}}$ & $199,74^{\mathrm{bc}}$ \\
\hline & {$[\mathrm{Br}]$} & $157,58^{\mathrm{efg}}$ & $156,73^{\mathrm{ef}}$ & $178,26^{\mathrm{cd}}$ & $166,59^{\mathrm{cd}}$ & $168,97^{\mathrm{de}}$ & $190,43^{\mathrm{bcd}}$ \\
\hline & {$[\mathrm{I}]$} & $167,18^{\text {cde }}$ & $177,04^{\mathrm{cd}}$ & $175,90^{\text {cd }}$ & $190,75^{\mathrm{bc}}$ & $190,23^{\mathrm{b}}$ & $183,83^{\text {cd }}$ \\
\hline \multirow{3}{*}{5.00} & {$[\mathrm{Cl}]$} & $146,00^{\mathrm{gh}}$ & $162,07^{\mathrm{def}}$ & $175,01^{\mathrm{cd}}$ & $173,75^{\text {cd }}$ & $159,41^{\mathrm{de}}$ & $188,26^{\mathrm{de}}$ \\
\hline & {$[\mathrm{Br}]$} & $139,48^{\mathrm{h}}$ & $150,63^{f}$ & $170,76^{\mathrm{d}}$ & $161,18^{\mathrm{d}}$ & $157,32^{\mathrm{e}}$ & $176,48^{\mathrm{f}}$ \\
\hline & {$[\mathrm{I}]$} & $147,93^{\mathrm{gh}}$ & $161,83^{\mathrm{def}}$ & $180,43^{\mathrm{cd}}$ & $166,93^{\text {cd }}$ & $176,03^{\mathrm{cd}}$ & $179,25^{\text {ef }}$ \\
\hline
\end{tabular}

Values denoted with the same letter for each day do not differ statistically at $p<0.05$

the activity of soil phosphatases are often used as indexes of soil fertility, as they play an important role in the process of organic phosphorus compounds transformation into inorganic phosphates (Parelho et al., 2016). The inhibition of the activity of phosphatases and other soil enzymes under the influence of different ionic liquids, deepened with the increase of dose, was demonstrated in previous studies (Telesiński et al., 2016b; Telesiński \& Sułkowska, 2016;
Telesiński et al., 2017). Numerous authors further report the negative effect of quaternary ammonium salts, including ionic liquids on the activity of microorganisms, which constitute the main source of enzymes in soil (Wang et al., 2011; Yu \& Nie, 2011; Guo et al., 2015; Mester et al., 2015; Saldago et al., 2017). Sun et al. (2017) demonstrated that the activity of soil phosphatases and dehydrogenases was not subjected to significant changes under the influence 
of 1-methyl-2-octylimidiazolium tetrafluoroborate. Nannipieri et al. (2011) state that a detailed interpretation of the influence of ionic liquids, as well as other xenobiotics, on the activity of soil phosphatases constitutes a problem due to the direct and indirect influence of other factors. The inhibition of enzyme activity by a specific contamination may be shadowed as a result of an elevated growth of immune microorganisms, which are characterized by expression of genes coding the given enzyme. The relative increase of biomass results from the growing microorganism population, capable of withstanding the presence of a xenobiotic, as well as using the remains of the sensitive microorganisms as a nutrition source (Telesiński et al., 2017).

One of the better indexes of soil ecosystem sensitivity to different stress factors is the one proposed by Orwin and Wardle (2004) resistance index (RS). It provides information about the status of soil environments contaminated with organic compounds (Kaczyńska et al., 2015).

The calculated mean RS values in the case of all [TEA] salts decreased with the increase of their dose (Fig. 1). On their basis, a clear influence of the anion was observed on the effect of these substances on the activity of soil phosphatases. This corroborates the study conducted earlier on the ecotoxicity of ionic liquids in relation to soil enzymes (Telesiński et al., 2016b), as well as their phytotoxicity (Biczak et al., 2014). Zhang et al. (2017), who examined different ionic liquids, determined that the length of alkyl substituents in a cation has a greater toxic influence on the zebrafish (Danio rerio) than the anion type. Based on the results of the present study, it was determined that in the case of Pac, the lowest RS values for all concentrations took place after the application of [TEA][Br]. In the case of the activity of the remaining phosphatases, such a relationship was observed only for the doses of 0.50 and $5.00 \mathrm{mmol} \cdot \mathrm{kg}^{-1}$. The literature contains information on the negative impact of bromides on microorganisms and enzymes they produce (Klose \& Ajwa, 2004; Stromberger et al., 2005). Based on the RS values, it can be further stated that the highest sensitivity to [TEA] salts characterized phosphomonoesterases, which confirms the earlier study on the toxicity of ionic liquids (Telesiński et al., 2016b, Telesiński et al., 2017).

\section{Conclusions}

The following conclusions can be drawn from the results and discussion presented in this paper:

1. The presence of salts with tetraethylammonium [TEA] cation at the low dose $\left(0.05 \mathrm{mmol} \cdot \mathrm{kg}^{-1}\right)$ mostly resulted in the stimulation of the activity of soil phosphatases. Higher doses of the salts had mostly inhibitory effect on activity of phosphatases.

2. Among the determined enzymes, phosphomonoesterases turned out to be the most sensitive to salts containing [TEA] cation.

3. The anion type had a considerable influence on the effect of salts with [TEA] cation on the formation of activity of the determined enzymes of phosphorus compound transformations, and the highest level of influence characterized tetraethylammonium bromide [TEA] $[\mathrm{Br}]$.

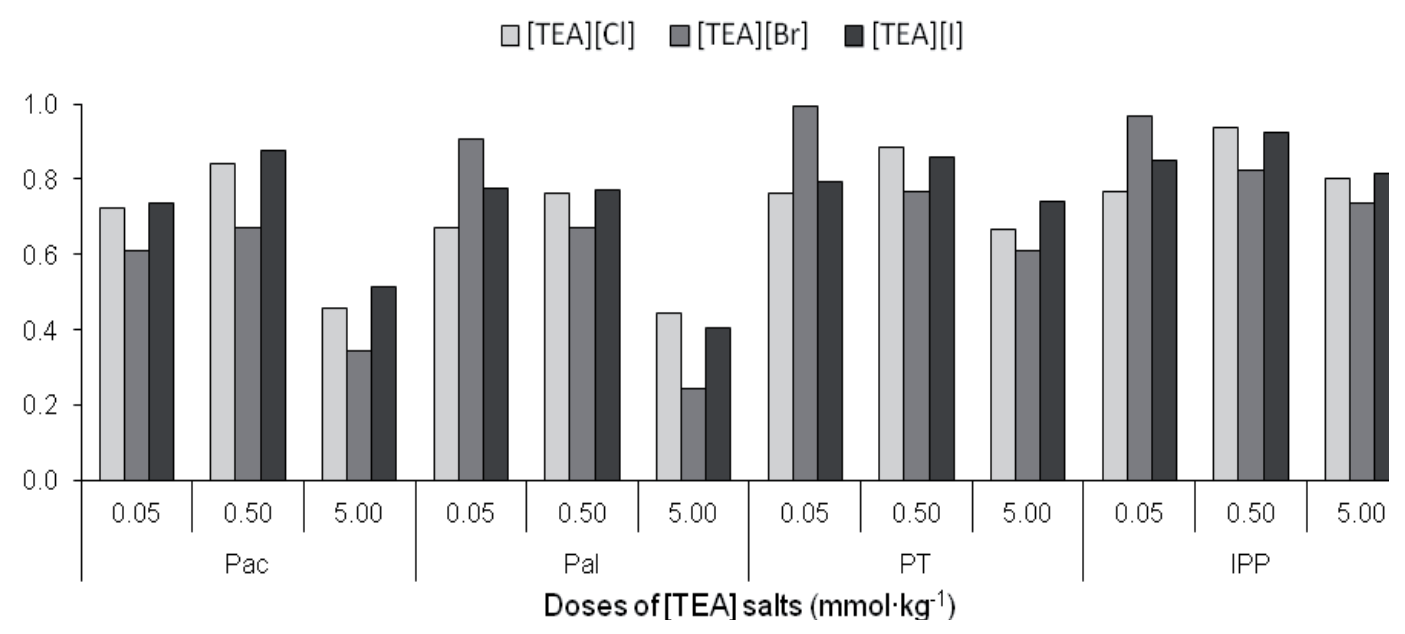

Figure 1. Mean values of resistance index (RS) in activity of phosphatases in loamy sand treated with [TEA] salts 


\section{References}

Banerjee A., Sanyal S. \& Sen S., 2012, Soil phosphatase activity of agricultural land: A possible index of soil fertility. Agricultural Science Research Journals 2(7): 412-419.

Biczak R., Pawłowska B., Białczewski P. \& Rychter P., 2014, The role of the anion in the toxicity of imidazolium ionic liquids. Journal of Hazardous Materials 274: 181-190.

Biczak R., Telesiński A. \& Pawłowska B., 2016, Oxidative stress in spring barley and common radish exposed to quaternary ammonium salts with hexafluorophosphate anion. Plant Physiology and Biochemistry 107: 248256.

Burns R.G., DeForest J.L., Marxsen J., Sinsabaugh R.L., Stromberger M.E., Wallenstein M.D., Weintraubg M.N. \& Zoppini A., 2013, Soil enzymes in a changing environment: Current knowledge and future directions. Soil Biology and Biochemistry 58: 216-234.

Dick W.A. \& Tabatabai M.A., 1978, Inorganic pyrophosphatase activity of soils. Soil Biology and Biochemistry 10: 59-65.

Eivazi F. \& Tabatabai M.A., 1977, Phosphatases in soils. Soil Biology and Biochemistry 9: 167-172.

Futa B., Patkowski K., Bielińska E.J., Gruszecki T.M., Pluta M., Kulik M. \& Chmielewski S., 2016, Sheep and horse grazing in a large-scale protection area and its positive impact on chemical and biological soil properties. Polish Journal of Soil Science 49(2): 111-122.

Grabińska-Sota E., 2004, Ocena oddziaływania czwartorzędowych soli amoniowych na środowisko wodne [Evaluation of impact of quaternary ammonium chlorides on water environment]. Politechnika Śląska, Zeszyty Naukowe 1613, Gliwice.

Guo P., Zhu L., Wang J., Wang J. \& Liu T., 2015, Effects of alkyl-imidazolium ionic liquid [Omim] $\mathrm{Cl}$ on the functional diversity of soil microbial communities. Environmental Science and Pollution Research 22: 9059-9066.

Kaczyńska G., Borowik A. \& Wyszkowska J., 2015, Soil dehydrogenases as an indicator of contamination of the environment with petroleum products. Water, Air and Soil Pollution 226(11): 372.

Klose S. \& Ajwa H.A., 2004, Enzyme activities in agricultural soil fumigated with methyl btomide alternatives. Soil Biology and Biochemistry 36: 1625-1635.

Mester P., Wagner M. \& Rossmanith P., 2015, Antimicrobial effects of short chained imidazolium based ionic liquids - Influence of anion chaotropicity. Ecotoxicology and Environmental Safety 111: 96-101.

Matzke M., Stolte S., Thiele K., Juffernholz T., Arning J., Ranke J., Welz-Biermann U. \& Jastorff B., 2007,
The influence of anion species on the toxicity of1alkyl-3-methylimidazolium ionic liquids observed in an (eco)toxicologicaltest battery. Green Chemistry 9: 1198-1207.

Nannipieri P., Giagnoni L., Landi L. \& Renella G., 2011, Role of phosphatase enzymes in soil, [in:] E.K. Bünemann, A. Oberson, E. Frossard (eds), Phosphorus in action. Springer-Verlag, Berlin, Heidelberg: 215-243.

Olander L.P. \& Vitousek P.M., 2000, Regulation of soil phosphatase and chitinase activity by $\mathrm{N}$ and $\mathrm{P}$ availability. Biogeochemistry 49: 175-190.

Orwin K.H. \& Wardle D.A., 2004, New indices for quantifying the resistance and resilience of soil biota to exogenous disturbance. Soil Biology and Biochemistry 36: 1907-1912.

Parelho C., Rodrigues A.S., Barreto M.C., Ferreira N.G.C. \& Garcia P., 2016, Assessing microbial activities in metal contaminated agricultural volcanic soils - an integrative approach. Ecotoxicology and Environmental Safety 129: 242-249.

Park S. \& Kim K., 2017, Tetramethylammonium tetrafluoroborate: The smallest quaternary ammonium tetrafluoroborate salt for use in electrochemical double layer capacitors. Journal of Power Sources 338: 129-135.

Pernak J., 2013, Aktywność biologiczna soli zawierających czwartorzędowy atom azotu [Biological activity of the salts containing a quaternary nitrogen atom]. Przemysł Chemiczny 92(9): 1653-1656.

Płatkowski M. \& Telesiński A., 2016, Response of soil phosphatases to glyphosate and its formulations Roundup (laboratory conditions). Plant, Soil and Environment 62(6): 286-292.

Salgado J., Parajó J.J., Teijeira T., Cruz O., Proupín J., Villanueva M., Rodríguez-Añón J.A., Verdes P.V. \& Reyes O., 2017, New insight into the environmental impact of two imidazolium ionic liquids. Effects on seed germination and soil microbial activity. Chemosphere 185 : 665-672.

Stromberger M.E., Klose S., Ajwa H., Trout T. \& Fennimore S., 2005, Microbial populations and enzyme activities in soils fumigated with methyl bromide alternatives. Soil Science Society of America Journal 69: 1987-1999.

Sun X., Zhu L., Wang J., Wang J., Su J., Liu T., Zhang C., Gao C. \& Shao Y., 2017, Toxic effects of ionic liquid 1-octyl-3-methylimidazolium tetrafluoroborate on soil enzyme activity and soil microbial community diversity. Ecotoxicology and Environmental Safety 135: 201-208.

Tabatabai M.A. \& Bremner J.M., 1969, Use of p-nitrophenyl phosphate for assay of soil phosphatase activity. Soil Biology and Biochemistry 1: 301-307.

Telesiński A., Śnioszek M., Biczak R. \& Pawłowska B., 2016a, Zagrożenia środowiskowe i toksykologiczne 
wynikające ze stosowania czwartorzędowych soli amoniowych [Environmental and toxicological risk of using quaternary ammonium salts]. Kosmos 65(4): 495-502.

Telesiński A., Biczak R., Pawłowska B., Stręk M. \& Pawłowski M., 2016b, Porównanie ekotoksyczności 1-butylo-2,3-dimetyloimidazoliowych cieczy jonowych $\mathrm{z}$ anionem tetrafluoroboranowym i heksafluorofosforanowym w stosunku do wybranych enzymów glebowych [Comparison of ecotoxicity of 1-butyl-2,3dimethylimidazolium ionic liquids with tetrafluoroborate and hexafluorophosphate anion for selected soil enzymes]. Zeszyty Problemowe Postępów Nauk Rolniczych 587: 23-30.

Telesiński A. \& Sułkowska N., 2016, Dynamika zanikania 1-alkilo-3-metyloimidazoliowych cieczy jonowych w aspekcie ich oddziaływania na aktywność oksydazy o-difenolowej w glebie [Dissipation dynamic of 1-alkyl-3-methylimidazolium ionic liquids and their effect on o-diphenol oxidase activity in soil]. Chemistry. Environment. Biotechnology 19: 87-92.
Telesiński A., Śnioszek M., Biczak R. \& Pawłowska B., 2017, Response of soil phosphatases to three different ionic liquids with hexafluorophosphate anion. Journal of Ecological Engineering 18(2): 86-91.

Wang H., Malhorta S.V. \& Francis A.J., 2011, Toxicity of various anions associated with methoxyethyl methyl imidazolium-based ionic liquids on Clostridium sp. Chemosphere 82 (11): 1597-1603.

Wang R., Dorodnikov M., Yang S., Zhang Y. Filley T.R, Turco R.F., Zhang Y., Xu Z., Li H. \& Jiang Y., 2015, Responses of enzymatic activities within soil aggregates to 9-year nitrogen and water addition in a semi-arid grassland. Soil Biology and Biochemistry 81: 159-167.

Yu Y. \& Nie Y., 2011, Toxicity and antimicrobial activities of ionic liquids with halogen anion. Journal of Environmental Protection 2(3): 298-303.

Zhang C., Zhu L., Wang J., Wang J., Zhou T., Xu Y. \& Cheng C., 2017, The acute toxic effects of imidazolium-based ionic liquids with different alkyl-chain lengths and anions on zebrafish (Danio rerio). Ecotoxicology and Environmental Safety 140: 235-240. 